

\title{
Inhibition of Fungi and Gram-Negative Bacteria by Bacteriocin BacTN635 Produced by Lactobacillus plantarum sp. TN635
}

Slim Smaoui, Lobna Elleuch, Wacim Bejar, Ines Karray-Rebai, Imen Ayadi, Bassem Jaouadi, Florence Mathieu, Hichem Chouayekh, Samir Bejar, Lofti

\author{
Mellouli
}

\section{To cite this version:}

Slim Smaoui, Lobna Elleuch, Wacim Bejar, Ines Karray-Rebai, Imen Ayadi, et al.. Inhibition of Fungi and Gram-Negative Bacteria by Bacteriocin BacTN635 Produced by Lactobacillus plantarum sp. TN635. Applied Chemistry and Biotechnology, 2010, vol. 162, pp. 1132-1146. 10.1007/s12010009-8821-7 . hal-00725453

\section{HAL Id: hal-00725453 https://hal.science/hal-00725453}

Submitted on 27 Aug 2012

HAL is a multi-disciplinary open access archive for the deposit and dissemination of scientific research documents, whether they are published or not. The documents may come from teaching and research institutions in France or abroad, or from public or private research centers.
L'archive ouverte pluridisciplinaire HAL, est destinée au dépôt et à la diffusion de documents scientifiques de niveau recherche, publiés ou non, émanant des établissements d'enseignement et de recherche français ou étrangers, des laboratoires publics ou privés. 


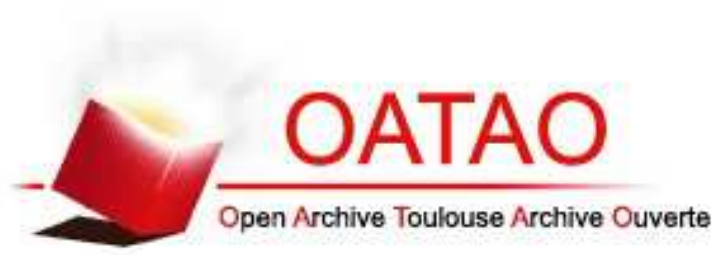

\section{Open Archive Toulouse Archive Ouverte (OATAO)}

OATAO is an open access repository that collects the work of Toulouse researchers and makes it freely available over the web where possible.

This is an author-deposited version published in: http://oatao.univ-toulouse.fr/ Eprints ID: 5699

To link to this article: DOI:10.1007/s12010-009-8821-7

URL: http://dx.doi.org/10.1007/s12010-009-8821-7

To cite this version: Smaoui, Slim and Elleuch, Lobna and Bejar, Wacim and Karrai-Rebai, Ines and Ayadi, Imen and Jaouadi, Bassem and Chouayekh, Hichem and Bejar, Samir and Mellouli, Lofti and Mathieu, Florence (2010) Inhibition of Fungi and Gram-Negative Bacteria by Bacteriocin BacTN635 Produced by Lactobacillus plantarum sp. TN635. Applied Chemistry and Biotechnology pp. 1132-1146. ISSN 0273-2289

Any correspondence concerning this service should be sent to the repository administrator: staff-oatao@listes.diff.inp-toulouse.fr 


\title{
Inhibition of Fungi and Gram-Negative Bacteria by Bacteriocin BacTN635 Produced by Lactobacillus plantarum sp. TN635
}

\author{
Slim Smaoui • Lobna Elleuch • Wacim Bejar • Ines Karray-Rebai • Imen Ayadi • \\ Bassem Jaouadi • Florence Mathieu • Hichem Chouayekh • Samir Bejar • \\ Lotfi Mellouli
}

\begin{abstract}
The aim of this study was to evaluate 54 lactic acid bacteria (LAB) strains isolated from meat, fermented vegetables and dairy products for their capacity to produce antimicrobial activities against several bacteria and fungi. The strain designed TN635 has been selected for advanced studies. The supernatant culture of this strain inhibits the growth of all tested pathogenic including the four Gram-negative bacteria (Salmonella enterica ATCC43972, Pseudomonas aeruginosa ATCC 49189, Hafnia sp. and Serratia sp.) and the pathogenic fungus Candida tropicalis R2 CIP203. Based on the nucleotide sequence of the 16S rRNA gene of the strain TN635 (1,540 pb accession no FN252881) and the phylogenetic analysis, we propose the assignment of our new isolate bacterium as Lactobacillus plantarum sp. TN635 strain. Its antimicrobial compound was determined as a proteinaceous substance, stable to heat and to treatment with surfactants and organic solvents. Highest antimicrobial activity was found between $\mathrm{pH} 3$ and 11 with an optimum at $\mathrm{pH}=7$. The BacTN635 was purified to homogeneity by a four-step protocol involving ammonium sulfate precipitation, centrifugal microconcentrators with a $10-\mathrm{kDa}$ membrane cutoff, gel filtration Sephadex G-25, and C18 reverse-phase HPLC. SDS-PAGE analysis of the purified BacTN635, revealed a single band with an estimated molecular mass of approximately $4 \mathrm{kDa}$. The maximum bacteriocin production $(5,000 \mathrm{AU} / \mathrm{ml})$ was recorded after a 16-h incubation in Man, Rogosa, and Sharpe (MRS) medium at $30^{\circ} \mathrm{C}$. The mode of
\end{abstract}

S. Smaoui $\cdot$ L. Elleuch $\cdot$ W. Bejar $\cdot$ I. Karray-Rebai $\cdot$ I. Ayadi $\cdot$ B. Jaouadi $\cdot$ H. Chouayekh $\cdot$ S. Bejar $\cdot$ L. Mellouli

Laboratoire d'Enzymes et de Métabolites des Procaryotes (LEMP), Centre de Biotechnologie de Sfax (CBS), Route de Sidi Mansour Km 6, B.P. "1177”, 3018 Sfax, Tunisia

F. Mathieu

Département « Bioprocédés \& Systèmes Microbiens » INP-ENSAT, Université de Toulouse, Laboratoire de Génie Chimique UMR 5503 (CNRS/INPT/UPS), 1 Av, de l'Agrobiopôle, BP 32607, 31326 CastanetTolosan, France

L. Mellouli $(\triangle)$

Laboratoire d'Enzymes et de Métabolites des Procaryotes, Centre de Biotechnologie de Sfax, B.P

"1177", Route Sidi Mansour Km 6, 3018 Sfax, Tunisia

e-mail: lotfi.mallouli@cbs.rnrt.tn 
action of the partial purified BacTN635 was identified as bactericidal against Listeria ivanovii BUG 496 and as fungistatic against C. tropicalis R2 CIP203.

Keywords Lactobacillus plantarum sp. TN635 - Identification - BacTN635 - Purification · Broad inhibitory spectrum

\section{Introduction}

During the last two decades, with the misuse use of existing antibiotics in human and veterinary medicine and in agriculture, the effectiveness of currently available antibiotics is decreasing due to the increasing number of resistant pathogenic strains. This is presently an urgent focus of research and it becomes inevitable to discover new antimicrobial agents for combating such a problem. Numerous antibacterial agents are now being considered, such as bacteriophage [1], probiotic bacteria [2], antimicrobial peptides [3], and bacteriocins [4]. Bacteriocins are ribosomally synthesized peptides with a narrower spectrum of antimicrobial activity than most antibiotics [5]. Their antimicrobial activity has been found more effective against closely related strains [6]. Actually, attention is turning to the potential application of bacteriocins in the protection of human health [7], in agriculture [8], and in food preservation [9]. Although bacteriocins are produced by many Gram-positive and Gram-negative bacteria, those produced by lactic acid bacteria (LAB) are of particular interest because they are known as "good bacteria" and can be used as natural preservatives in food industry [10]. During the last few years, a large number of new LAB bacteriocins have been identified and characterized. However, only few have been described to possess activities against Gram-negative bacteria, e.g., plantaricin 35d produced by Lactobacillus plantarum [11], bacteriocin ST34BR produced by L. lactis subsp. Lactis [12], bacteriocins ST26MS and ST28MS produced by L. plantarum [13] and bacteriocin AMA-K produced by L. plantarum AMA-K [14].

During our search program for bioactive compounds from LAB, a new bacterium called TN635 was selected. This paper describes the selection, identification, and phylogenetic determination of this bacterium. The purification and the characterization of a bacteriocinlike substance called BacTN635, from the supernatant culture of this new strain are also reported.

\section{Materials and Methods}

Bacterial Strains and Plasmids

The TN635 strain was selected as a producer of potent antimicrobial activities and was used as the source of chromosomal DNA to amplify the 16S rRNA gene. E. coli TOP10 (Invitrogen), F-mcrA $\Delta$ (mrr-hsdRMS-mcrBC) $\phi 80$ lacZ $\Delta \mathrm{M} 15 \Delta$ lacX74 deo R recA1 araD139 $\Delta$ (ara-leu)7697 galU galK rpsL endA1 nupG, and E. coli DH5 $\alpha$ [15] were used as host strains. Bacterial strains: Gram-positive bacteria (Micrococcus luteus LB 14110, Staphylococcus aureus ATCC 6538, Listeria ivanovii BUG 496, Enterococcus faecalis JH 2-2 and Enterococcus faecium ENSAIA 631), Gram-negative bacteria (Escherichia coli ATCC 8739, Salmonella enterica ATCC43972, Pseudomonas aeruginosa ATCC 49189, Hafnia sp. and Serratia sp.), and lactic acid bacteria: (Lactobacillus casei DSM 20011, Lactobacillus sakei 2525, Lactobacillus delbrueckii DSM 20081, Lactococcus lactis ATCC 
11454 and Lactococcus lactis subsp. cremoris DSM 11603) were used as indicator microorganisms for the antibacterial activity assays. Antifungal activity was determined against the Fusarium sp. and Candida tropicalis R2 CIP203.

pIJ2925 [16] derivative of pUC18 and pCR-Blunt vector (Invitrogen) Col E1 origin (pUC-derived) $\mathrm{Kn}^{\mathrm{R}}$ were used as the cloning vectors. $\mathrm{pSS} 1$, derivative of pCR-Blunt vector carrying a 1,540-bp DNA fragment corresponding to the whole $16 \mathrm{~S}$ rRNA gene of the TN635 strain (this work).

\section{Culture Conditions}

E. coli $\mathrm{DH} 5 \alpha$ was grown on Luria Bertani (LB) plates supplemented with ampicillin $(50 \mu \mathrm{g} / \mathrm{ml})$ and 5-bromo-4-chloro-3-indolyl- $\beta$-D-galactopyranoside $(40 \mu \mathrm{g} / \mathrm{ml})$ when appropriate [17]. Transformation of E. coli DH5 $\alpha$ with pIJ2925 derivatives was carried out according to Hanahan [15]. Growth and transformation of TOP10 E. coli strain with the pCR-Blunt vector derivative were carried out according to the manufacturer's instructions (Invitrogen). For determination of antibacterial activities, indicator microorganisms were grown overnight in LB medium in aerobic conditions at $30^{\circ} \mathrm{C}$ for Lb. casei DSM 20011, Lb. sakei 2525, Lc. lactis ATCC 11454, Lc. lactis subsp. cremoris DSM 11603, L. ivanovii BUG 496, S. enterica ATCC43972, P. aeruginosa ATCC 49189, and M. luteus LB 14110, in aerobic conditions at $37^{\circ} \mathrm{C}$ for E. coli ATCC 8739 and S. aureus ATCC 6538, in anaerobic conditions at $30^{\circ} \mathrm{C}$ for E. faecalis JH 2-2, E. faecium ENSAIA 631, Hafnia sp and Serratia sp, and in anaerobic conditions at $37^{\circ} \mathrm{C}$ for Lb. delbrueckii DSM 20081. For antifungal activities determination, Fusarium sp. was grown in potato dextrose agar (PDA) for 7 days at $30^{\circ} \mathrm{C}$. Spores were collected in sterile distilled water and then concentrated to produce a suspension with approximately $10^{4}$ spores $/ \mathrm{ml}$. C. tropicalis R2 CIP203 was grown in YP10 medium ( $10 \mathrm{~g} / 1$ yeast extract, $10 \mathrm{~g} / 1$ peptone, $100 \mathrm{~g} / 1$ glucose, $15 \mathrm{ml}$ of $2 \mathrm{~g} /$ 1 adenine solution) at $30^{\circ} \mathrm{C}$ for $24 \mathrm{~h}$ in an orbital incubator with shaking at $200 \mathrm{rpm}$. The TN635 strain was maintained as frozen stocks at $-80^{\circ} \mathrm{C}$ in Man, Rogosa, and Sharpe (MRS) broth containing 20\% ( $v / v)$ glycerol. Before experimental use, the cultures were propagated twice in MRS medium at $30^{\circ} \mathrm{C}$ for $12 \mathrm{~h}$ and the transfer inoculum was $1 \%(v / v)$.

DNA Isolation and Manipulation

Total DNA preparation from TN635 strain was carried out according to the method of Leenhouts et al. [18] with slight modifications as described by Lee et al. [19]. Small-scale plasmid preparations from E. coli were performed as described by Sambrook et al. [17]. Digestion with restriction endonucleases, separation of DNA fragments by agarose gels electrophoresis, dephosphorylation with alkaline calf intestinal phosphatase, ligation of DNA fragments, and transformation of E. coli were performed according to Sambrook et al. [17].

PCR Amplification of the 16S rRNA Gene of TN635 Strain

PCR amplification of the 16S rRNA gene of TN635 strain was performed using two specific primers P1: 5'-AGAGTTTGATCCTGGCTCAG-3' and P2: 5'-ATGGCTCAGGAC GAACGCT-3'. Approximately $200 \mathrm{ng}$ genomic template DNA was used with $150 \mathrm{pmol}$ of each primer per $50 \mu \mathrm{l}$ reaction volume. Amplification was performed in an automated thermocycler (Perkin Elmer) using 1 U Pfu DNA polymerase (Stratagene) according to the following amplification profile: $94^{\circ} \mathrm{C}(3 \mathrm{~min})$ followed by 40 cycles of denaturation at $94^{\circ} \mathrm{C}$ $(30 \mathrm{~s})$, annealing at $60^{\circ} \mathrm{C}(1 \mathrm{~min})$, and extension at $72^{\circ} \mathrm{C}(3 \mathrm{~min})$. 
DNA Sequencing and Analysis

Nucleotide sequence of the whole 16S rRNA gene of TN635 strain was determined on both strands by an automated 3100 Genetic Analyser (Applied Biosystems) using specific primers. Homology search was performed using Blast Search algorithm. The nucleotide sequence of the whole $16 \mathrm{~S}$ rRNA gene $(1,540 \mathrm{pb})$ of TN635 strain has been assigned GenBank (EMBL) under accession number FN252881. Multiple sequence alignment was carried out using CLUSTAL W [20] at the European Bioinformatics Institute website (http://www.ebi.ac.uk/clustalw/). Phylogenetic analyses were performed using programs from the PHYLIP package [21] and phylogenetic tree was constructed by the neighborjoining (NJ) algorithm [22] using Kimura ten-parameter distance. The robustness of the inferred tree was evaluated by bootstrap (100 replications).

\section{Antimicrobial Activities Determination}

The ability of TN635 strain to produce diffusible metabolites was tested by the agar well diffusion assay [23]. The diameters of the inhibition zones were measured. The bacteriocin samples to be spotted were serially diluted twofold, and the reciprocal of the highest inhibitory dilution was used to calculate the arbitrary activity units (AU) per milliliter. The un-inoculated media were also tested for inhibitory zones as a control.

Effect of Different Treatments on the Antimicrobial Activity of the TN635 Strain

The indicator strains used in these experiments were: L. ivanovii BUG 496, S. enterica ATCC43972, S. aureus ATCC 6538, E. faecalis JH 2-2 and E. faecium ENSAIA 631, and the pathogenic fungus $C$. tropicalis R2 CIP203. All determinations were carried out simultaneously three times under the same conditions. For each determination, control tests were realized without the corresponding treatment.

\section{Effect of Temperature and Stability at Different $\mathrm{pH}$}

Cultures of the TN635 strain in MRS broth under anaerobic condition were maintained at different temperatures $\left(25,30,37\right.$, and $\left.45^{\circ} \mathrm{C}\right)$. The growth was followed by measuring the optical density (OD) at $600 \mathrm{~nm}$. Sensitivity to heat of antimicrobial compounds was investigated by treating the 16 -h culture supernatant of the TN635 strain growing at $30^{\circ} \mathrm{C}$ in water bath at $45,70,85$, and $100^{\circ} \mathrm{C}$ for $90 \mathrm{~min}$ and $2 \mathrm{~h}$ and by autoclaving $(20 \mathrm{~min}$ at $121^{\circ} \mathrm{C}$ ). In order to determine the sensitivity of the bacteriocin to $\mathrm{pH}$, the supernatant of the TN635 strain culture $\left(30^{\circ} \mathrm{C}, 16 \mathrm{~h}\right.$ incubation) was adjusted to $\mathrm{pH}$ levels ranging from 1 to 14 (intervals of 1.0) with sterile $1 \mathrm{~N} \mathrm{HCl}$ or $1 \mathrm{~N} \mathrm{NaOH}$ and kept at $4^{\circ} \mathrm{C}$ for $6 \mathrm{~h}$. The treated supernatants were adjusted to $\mathrm{pH} 7.0$ and tested for their antimicrobial activities as previously described.

\section{Sensitivity to Different Enzymes and Surfactants}

In order to determine the biological nature of the antimicrobial activity produced by the strain TN635, $1 \mathrm{ml}$ of the cell-free supernatant was incubated for $3 \mathrm{~h}$ at $37^{\circ} \mathrm{C}$ in the presence of $1 \mathrm{mg} / \mathrm{ml}$ catalase (Boehringer). The untreated bacteriocin-containing cell-free supernatant served as control. Sensitivity to proteolytic, lipolytic and $\alpha$-amylase enzymes of antimicrobial compounds was investigated by the addition of Trypsin, pronase E (Sigma), 
Proteinase K (Boehringer), lipase A (Sigma) and $\alpha$-amylase (Sigma) at final concentration of $1 \mathrm{mg} / \mathrm{ml}$ to the culture supernatants of the TN635 strain $\left(30^{\circ} \mathrm{C}, 16 \mathrm{~h}\right)$. The samples were incubated for $2 \mathrm{~h}$ at $37^{\circ} \mathrm{C}$ and immediately after, the residual activity was determined as described above. The surfactants used were Tween 20, Tween 80, urea, Triton X-100, sodium dodecyl sulfate (SDS), ethylenediaminetetraacetic acid (EDTA), and phenylmethanesulfonylfluoride (PMSF) which were added to the culture supernatants of the TN635 strain $\left(30^{\circ} \mathrm{C}, 16 \mathrm{~h}\right)$ at a final concentration of $1 \%(v / v)$ and incubated at $30^{\circ} \mathrm{C}$ for $2 \mathrm{~h}$. Surfactants at $1 \%$ in MRS broth were used as controls. All surfactants were prepared at $10 \%$ in water and filter-sterilized before use.

Effect of Organic Solvents

The culture supernatants of the TN635 strain $\left(30^{\circ} \mathrm{C}, 16 \mathrm{~h}\right)$ were mixed with various organic solvents (ethyl acetate, isopropanol and methanol) at a final concentration of $50 \%(\mathrm{v} / \mathrm{v})$. After incubation for $1 \mathrm{~h}$ at room temperature, the organic solvent was evaporated in a vacuum concentrator and the residual antimicrobial activity was determined.

Bacteriocin Purification, Molecular Weight Determination, and Zymogram Analysis

Strain TN635 was inoculated ( $1 \% v / v$ ) into $900 \mathrm{ml}$ (Duran bottles, containing $900 \mathrm{ml}$ of MRS broth), and incubated without agitation at $30^{\circ} \mathrm{C}$ until early stationary phase $(16 \mathrm{~h})$ corresponding to maximum bacteriocin production. For bacteriocin purification, proteins of the crude supernatant fluid (CSF) were precipitated with 40, 60, and 80\% saturated ammonium sulfate, gradually added by slow stirring during $4 \mathrm{~h}$ at $4{ }^{\circ} \mathrm{C}$. After centrifugation at $9,000 \times \mathrm{g}$ for $30 \mathrm{~min}$ at $4^{\circ} \mathrm{C}$, the precipitate was suspended in $10 \mathrm{ml}$ of $20 \mathrm{mmol} / \mathrm{l}$ sodium phosphate buffer ( $\mathrm{pH}$ 7.0) and desalted in centrifugal microconcentrators (Amicon, Inc.) with a $10-\mathrm{kDa}$ membrane cutoff. The resulting solution $(3.5 \mathrm{ml})$ was loaded on a column $(70 \times$ $1.5 \mathrm{~cm}$ ) of gel filtration Sephadex G-25 equilibrated with $20 \mathrm{mmol} / 1$ sodium phosphate buffer $(\mathrm{pH} 7)$. Elution of proteins was performed with the same buffer at $30 \mathrm{ml} / \mathrm{h} ; 140$ fractions (F1F140) with $5 \mathrm{ml}$ each were eluted from the Sephadex G-25 column and collected automatically. These 140 fractions detected using absorption measurements at $280 \mathrm{~nm}$ were fractioned into six samples (S1-S6): S1 (F1-F40), S2 (F41-F70), S3 (F71-F76), S4 (F77F81), S5 (F82-F93), and S6 (F94-F140). The antimicrobial activity of the different collected fractions was tested using L. ivanovii BUG 496, S. enterica ATCC43972, and C. tropicalis R2 CIP203 as an indicator strains. The active fraction was then applied to a second round of purification by a reverse-phase HPLC method using a C18 column $(300 \times 4.6 \mathrm{~mm})$ at a flow rate of $0.5 \mathrm{ml} / \mathrm{min}$. Bacteriocin was eluted from the column with two mobile phases: A (99.9\% water, 0.1\% trifluoroacetic acid "TFA") and B (99.9\% acetonitrile, 0.1\% TFA); from 0 to $5 \mathrm{~min}(90 \% \mathrm{~A}, 10 \% \mathrm{~B})$, from 5 to $30 \mathrm{~min}(50 \% \mathrm{~A}, 50 \% \mathrm{~B})$, from 30 to $35 \mathrm{~min}(20 \% \mathrm{~A}$, $80 \% \mathrm{~B})$, from 35 to $50 \mathrm{~min}(10 \% \mathrm{~A}, 90 \% \mathrm{~B})$ and from 50 to $60 \mathrm{~min}(90 \% \mathrm{~A}, 10 \% \mathrm{~B})$. Proteins were monitored at $280 \mathrm{~nm}$. The pooled biological active fraction obtained from HPLC elution was concentrated and stored at $-20^{\circ} \mathrm{C}$. The estimated molecular weight of the purified bacteriocin was determined by SDS-PAGE according to Laemmli [24] with $20 \%$ acrylamide gel. Protein concentration was measured using BSA as reference as described by Bradford [25]. The used protein marker is from BioLabs with a broad range of 2-212 kDa. To determine the apparent molecular mass of the bacteriocin, the gel was cut into two vertical parts after SDS-PAGE. The part of the gel containing the sample and the protein marker was stained with $0.25 \%$ Coomassie brilliant blue R-250 (BioRad), while the remaining part, containing only the sample, was washed in $10 \mathrm{mmol} / \mathrm{l}$ phosphate buffer $(\mathrm{pH} 7)$ for $4 \mathrm{~h}$, then 
fixed and used for direct detection of antimicrobial activity by overlaying with LB soft agar containing $100 \mu \mathrm{l}$ of a $5 \mathrm{~h}$ culture of L. ivanovii BUG 496.

\section{Mode of Action of BacTN635}

For this realization, we have used two indicator microorganisms: L. ivanovii BUG 496 and C. tropicalis R2 CIP203. Partially-purified BacTN635 (the fraction obtained from gel filtration chromatography and freeze-dried) at $400 \mathrm{AU} / \mathrm{ml}$, was added to $200 \mathrm{ml} \mathrm{LB}$ culture of L. ivanovii BUG 496 and $200 \mathrm{ml}$ YP10 of C. tropicalis R2 CIP203 at in early exponential phase $\left(10^{7}\right.$ colony-forming units $\left.(\mathrm{CFU}) / \mathrm{ml}\right)$. The two indicator microorganisms growing in LB (L. ivanovii BUG 496) and YP10 (C. tropicalis R2 CIP203) in the absence of bacteriocin were used as controls. Changes in the turbidity of the cultures were recorded at an O.D. of the $600 \mathrm{~nm}$ and the number of CFU was determined by plaiting the samples on LB or YP10 agar.

\section{Results and Discussion}

Screening of LAB Strains Producing Bacteriocin

During previous works (data not shown), a collection of $54 \mathrm{LAB}$ strains were isolated from several isolates (meat, fermented vegetables, and dairy products). We have tested these bacteria for their capacity to produce antimicrobial activities against the following indicator microorganisms: Lb. casei DSM 20011, L. ivanovii BUG 496, S. enterica ATCC43972, Fusarium sp., and C. tropicalis R2 CIP203. As shown in Table 1, different profiles of inhibition were observed. Nine strains (TN600, TN606, TN615, TN618, TN623, TN627, TN635, TN644, and TN653) were characterized by the broad-spectrum inhibition. These nine isolates were tested for their capacity to inhibit the growth of other microorganisms (Table 2). The largest spectrum of inhibition was showed by TN635 strain which inhibited all used indicator microorganisms. Moreover, the active molecule(s) of the TN635 strain presents the highest inhibitory effect against all tested microorganisms including the pathogenic Gram-positive bacteria (L. ivanovii BUG 496, S. aureus ATCC 6538, E. faecalis JH 2-2 and E. faecium ENSAIA 631), the four pathogenic Gram-negative bacteria $(S$. enterica ATCC43972, P. aeruginosa ATCC 49189, Hafnia sp. and Serratia sp.), and the pathogenic fungus $C$. tropicalis R2 CIP203. Since bacteriocins often have a narrow killing spectrum and inhibit only bacteria closely related to those from which they have been formed, bacteriocins from Gram-positive bacteria are generally not effective against Gramnegative bacteria and have no effect with yeasts and fungi $[26,27]$. The search for new bacteriocins with a wider spectrum of activity which can be used in human health, agriculture, and the food industry is being studied by several research groups. According to its large inhibitory spectrum, our finding, BacTN635 of the new isolated TN635 strain, may be of applied interest as food preservation and/or in the protection of human health.

Identification and Phylogenetic Analysis of TN635 Strain

Using the two specific primers: forward P1: 5'-AGAGTTTGATCCTGGCTCAG-3' and reverse P2: 5'-ATGGCTCAGGACGAACGCT-3' and the TN635 strain genomic DNA as template, we have amplified by PCR a DNA fragment having an expected size of approximately $1,500 \mathrm{pb}$. After purification, this DNA fragment was cloned in the pGEM-T 
Table 1 Inhibitory spectrum (zone of inhibition/mm) of the isolated 54 LAB (TN600- TN653) against $L b$. casei DSM 20011, L. ivanovii BUG 496, S. enterica ATCC43972, Fusarium.sp, and C. tropicalis R2 CIP203: L (listeria); Lb (Lactobacillus); C (Candida).

\begin{tabular}{|c|c|c|c|c|c|}
\hline \multirow[t]{2}{*}{ Isolates } & \multicolumn{5}{|c|}{ Indicator microorganisms } \\
\hline & $\begin{array}{l}\text { Lb. casei } \\
\text { DSM } 20011\end{array}$ & $\begin{array}{l}\text { L. ivanovii } \\
\text { BUG } 496\end{array}$ & $\begin{array}{l}\text { S. enterica } \\
\text { ATCC43972 }\end{array}$ & Fusarium sp. & $\begin{array}{l}\text { C. tropicalis } \\
\text { R2 CIP203 }\end{array}$ \\
\hline TN600 & 6 & 12 & 22 & 14 & 8 \\
\hline TN601 & - & 7 & - & - & - \\
\hline TN602 & - & - & - & - & - \\
\hline TN603 & 8 & - & - & - & 6 \\
\hline TN604 & - & - & - & 8 & 8 \\
\hline TN605 & 10 & 16 & 7 & 7 & - \\
\hline TN606 & 7 & 18 & 16 & 16 & 9 \\
\hline TN607 & 6 & 5 & - & - & - \\
\hline TN608 & 8 & 8 & 8 & - & - \\
\hline TN609 & 9 & - & 7 & 8 & - \\
\hline TN610 & - & 13 & 15 & - & - \\
\hline TN611 & - & - & - & - & - \\
\hline TN612 & - & - & - & - & - \\
\hline TN613 & 9 & 17 & 10 & - & 8 \\
\hline TN614 & - & 6 & 7 & 8 & 15 \\
\hline TN615 & 7 & 6 & 18 & 19 & 5 \\
\hline TN616 & 8 & - & - & 16 & - \\
\hline TN617 & - & - & - & 18 & - \\
\hline TN618 & 8 & 14 & 16 & 18 & 9 \\
\hline TN619 & 8 & 7 & - & 10 & - \\
\hline TN620 & 7 & 16 & - & - & - \\
\hline TN621 & 6 & - & - & 20 & - \\
\hline TN622 & - & 7 & 5 & - & 6 \\
\hline TN623 & 7 & 20 & 18 & 17 & 19 \\
\hline TN624 & 8 & 8 & 7 & 7 & - \\
\hline TN625 & 7 & 6 & 17 & - & - \\
\hline TN626 & - & - & - & - & - \\
\hline TN627 & 8 & 9 & 12 & 14 & 10 \\
\hline TN628 & - & - & 6 & 16 & - \\
\hline TN629 & 7 & - & - & 6 & - \\
\hline TN630 & 9 & 9 & - & 6 & 6 \\
\hline TN631 & - & 18 & 17 & 9 & - \\
\hline TN632 & - & 8 & 8 & - & - \\
\hline TN633 & 9 & - & - & - & 7 \\
\hline TN634 & 6 & - & 7 & 7 & - \\
\hline TN635 & 9 & 22 & 21 & 23 & 21 \\
\hline TN636 & 9 & 6 & - & 7 & - \\
\hline TN637 & 8 & 7 & - & 15 & - \\
\hline TN638 & 7 & - & 7 & 16 & - \\
\hline TN639 & - & 7 & 7 & 18 & 7 \\
\hline
\end{tabular}


Table 1 (continued).

\begin{tabular}{llcccc}
\hline Isolates & \multicolumn{2}{l}{ Indicator microorganisms } & & \\
\cline { 2 - 6 } & Lb. casei & L. ivanovii & S. enterica & Fusarium sp. & C. tropicalis \\
& DSM 20011 & BUG 496 & ATCC43972 & & R2 CIP203 \\
\hline TN640 & 7 & 7 & 8 & 6 & - \\
TN641 & - & 16 & 17 & - & 15 \\
TN642 & 6 & - & - & 16 & - \\
TN643 & - & 6 & 7 & 17 & 6 \\
TN644 & 7 & 16 & 6 & - & 6 \\
TN645 & 6 & 7 & 8 & 18 & 7 \\
TN646 & - & - & - & 8 & - \\
TN647 & 7 & - & 6 & 18 & - \\
TN648 & 8 & 8 & - & 16 & 6 \\
TN649 & - & - & 8 & 17 & 17 \\
TN650 & - & 16 & - & 7 & 6 \\
TN651 & 6 & - & 7 & 12 & 7 \\
TN652 & - & 16 & 17 & 8 \\
TN653 & 7 & & & 7 \\
\hline
\end{tabular}

Table 2 Inhibitory spectrum (zone of inhibition/mm) of TN600, TN606, TN615, TN618, TN623, TN627, TN635, TN 644 and TN653 strains against Gram-positive and Gram-negative bacteria, LAB and fungi: $L$ (listeria); Lb (Lactobacillus); Lc (Lactococcus); C (Candida).

\begin{tabular}{|c|c|c|c|c|c|c|c|c|c|}
\hline Indicator strains & TN600 & TN606 & TN615 & TN618 & TN623 & TN627 & TN635 & TN644 & TN653 \\
\hline \multicolumn{10}{|l|}{ Gram-positive bacteria } \\
\hline M. luteus LB 14110 & 23 & 14 & 6 & 14 & 14 & 6 & 23 & 14 & 11 \\
\hline S. aureus ATCC 6538 & 12 & 15 & 16 & 14 & 9 & 16 & 22 & 21 & 8 \\
\hline L. ivanovii BUG 496 & 12 & 18 & 6 & 16 & 20 & 9 & 22 & 16 & 16 \\
\hline E. faecalis $\mathrm{JH}$ 2-2 & 6 & 18 & 8 & - & 15 & 16 & 22 & 7 & 8 \\
\hline E. faecium ENSAIA 631 & 6 & 14 & 7 & - & 14 & 14 & 21 & 8 & 6 \\
\hline \multicolumn{10}{|l|}{ Gram-negative bacteria } \\
\hline E. coli ATCC 8739 & 5 & 22 & 13 & 15 & 15 & 23 & 22 & 13 & 22 \\
\hline S. enterica ATCC43972 & 22 & 16 & 18 & 16 & 18 & 12 & 21 & 6 & 17 \\
\hline P. aeruginosa ATCC 49189 & 22 & 16 & 6 & 9 & 14 & 9 & 22 & 8 & 9 \\
\hline Hafnia sp. & 5 & 15 & 6 & 13 & 24 & 6 & 24 & 5 & 7 \\
\hline Serratia sp. & 12 & 6 & 12 & 15 & 21 & 7 & 23 & 8 & 9 \\
\hline \multicolumn{10}{|l|}{ LAB } \\
\hline Lb. Casei DSM 20011 & 6 & 7 & 7 & 8 & 7 & 8 & 9 & 7 & 7 \\
\hline Lb. delbrueckii DSM 20081 & - & 6 & 8 & - & - & 9 & 9 & 6 & - \\
\hline Lb. Sakei 2525 & - & 6 & 7 & - & 7 & 6 & 9 & - & - \\
\hline Lc. lactis ATCC 11454 & - & - & 6 & 5 & 6 & 7 & 9 & - & 9 \\
\hline Lc. lactis cremoris DSM 11603 & - & - & 5 & 7 & 7 & 9 & 8 & - & 8 \\
\hline \multicolumn{10}{|l|}{ Fungi } \\
\hline Fusarium sp. & 14 & 16 & 19 & 18 & 17 & 14 & 23 & 22 & 18 \\
\hline C. tropicalis $\mathrm{R} 2 \mathrm{CIP} 203$ & 8 & 9 & 5 & 9 & 19 & 10 & 21 & 6 & 8 \\
\hline
\end{tabular}


Easy vector, yielding the pSS1 plasmid. Total nucleotide sequence of 1,540 pb (accession number FN252881) of the whole 16S rRNA gene of strain TN635 was determined in both strands. The alignment of this sequence through matching with reported 16S rRNA gene sequences in gene bank shows high similarity (97-99\%) to the Lactobacillus 16S rRNA genes. The organism most similar to the new isolate TN635 strain was L. plantarum NRIC 0383 (Fig. 1). Based on the nucleotide sequence of the 16S rRNA gene of the TN635 strain and the phylogenetic analysis, we propose the assignment of our new isolate bacterium as L. plantarum sp. TN635 strain.

Growth and Bacteriocin Production

To test the effect of incubation temperature on cell growth and antimicrobial activity production, cultures of the L. plantarum sp. TN635 strain in MRS broth under anaerobic conditions were maintained at different temperatures $\left(25,30,37\right.$, and $\left.45^{\circ} \mathrm{C}\right)$. The growth was followed by measuring the $\mathrm{OD}$ at $600 \mathrm{~nm}$ and the antimicrobial activity was determined against the three indicator microorganisms: L. ivanovii BUG 496, S. enterica ATCC43972, and C. tropicalis R2 CIP203. Aliquots were withdrawn at $3 \mathrm{~h}$ time intervals. Obtained results show that the secretion of biological activity is correlated with biomass production. Highest growth and antimicrobial activity were obtained at $30^{\circ} \mathrm{C}$ (Fig. 2). We can deduce that the extracellularly antimicrobial activity was produced in the logarithmic growth phase and the production profile was a typical growth associated patter. The maximum antimicrobial activity was detected $16 \mathrm{~h}$ after incubation. This activity remains stable between 13 and $20 \mathrm{~h}$ and then gradually decreased.

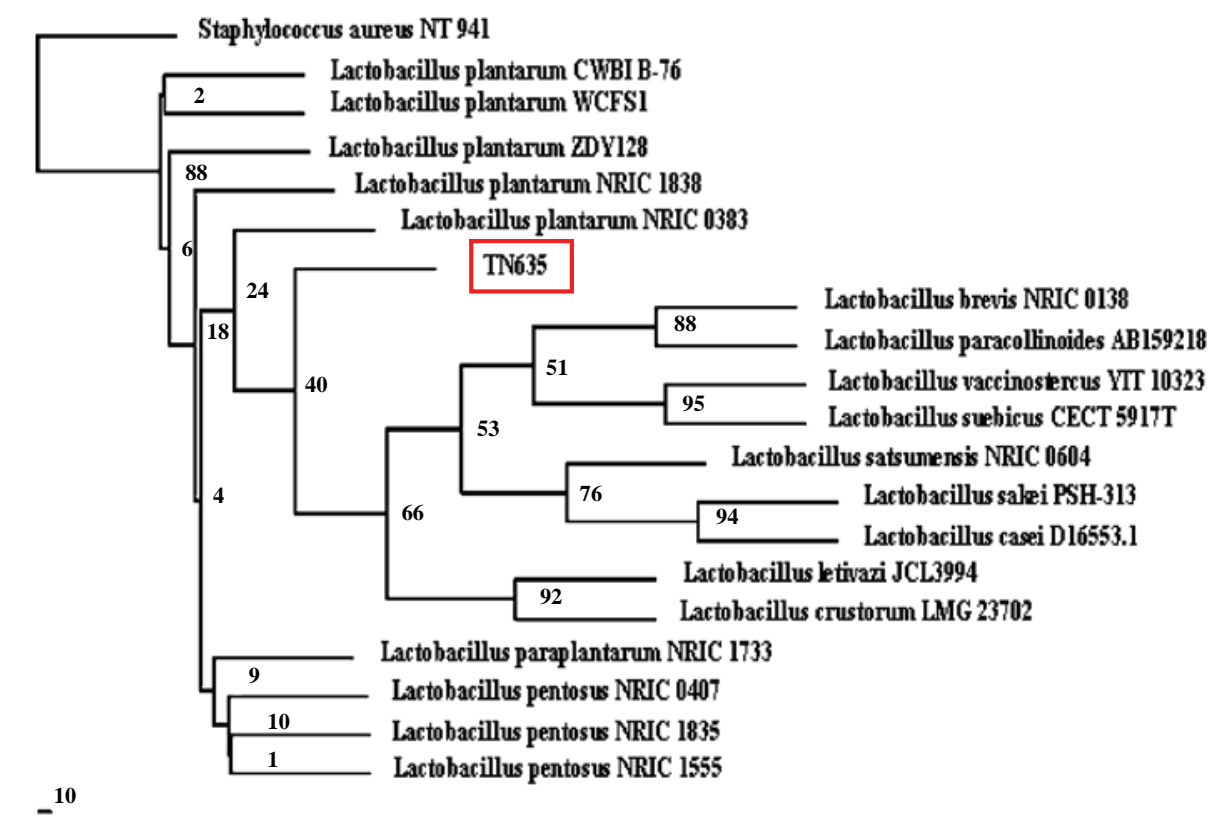

Fig. 1 Phylogenetic trees derived from 16S rDNA sequence of L. plantarum sp. TN635 strain. All the sequences used here were from LAB type strains 


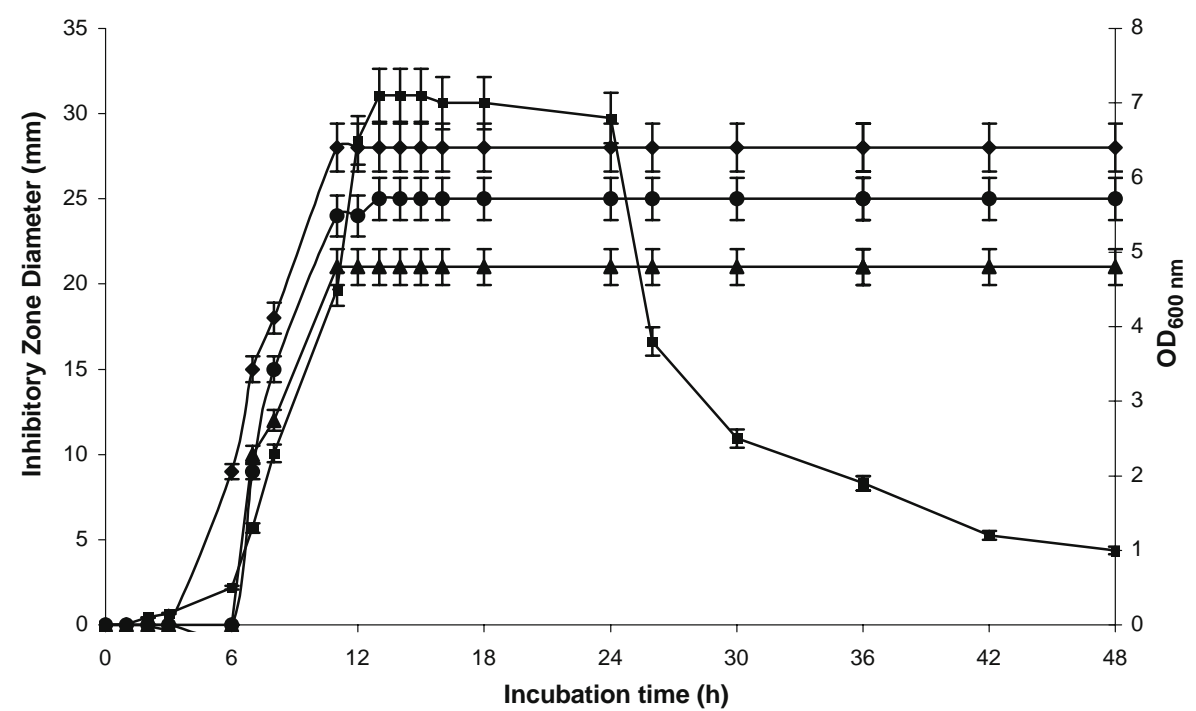

Fig. 2 BacTN635 production during growth of L. plantarum TN635 in MRS broth at $30^{\circ} \mathrm{C}$. (filled square) Optical density at $600 \mathrm{~nm}$; activities of BacTN635 against C. tropicalis R2 CIP203 (filled upright triangle); against S. enterica ATCC43972 (filled circle), and against L. ivanovii BUG 496 (filled diamond) were measured by diameter $(\mathrm{mm})$ of zone of inhibition

Effects of Enzymes, Heat, pH, Surfactants and Organic Solvents

Enzymatic tests showed that the antimicrobial activity against the three tested indicator microorganisms, L. ivanovii BUG 496, S. enterica ATCC43972, and C. tropicalis R2 CIP203, of the supernatant culture of the L. plantarum sp. TN635 strain was not affected by the addition of catalase, indicating that the observed growth inhibition was not due to hydrogen peroxide production. In contrast, treatment with the proteolytic enzymes (Trypsin, pronase E, and Proteinase K) caused complete inactivation of the antimicrobial compounds, which therefore identified them as proteinaceous substances. The sensitivity of the inhibitory compounds to heat treatment showed that inhibitory activity was not significantly altered by boiling for $90 \mathrm{~min}$ showing that the antagonistic activity of the culture supernatant is heat-resistant. The activity of the sample was insensitive to lipase and $\alpha$ amylase, which eliminates the possibility that synthesized active compounds are included in the group of complex biologically active substances containing a lipid or carbohydrate component [28]. Concerning the sensitivity to $\mathrm{pH}$, the supernatant culture of the $L b$. plantarum sp. TN635 $\left(30^{\circ} \mathrm{C}, 16 \mathrm{~h}\right.$ incubation) was adjusted to $\mathrm{pH}$ levels ranging from 1 to 14 (intervals of 1.0). The obtained results show that bacteriocin activity was highest when the $\mathrm{pH}$ of the supernatant was between 3 and 11, with an optimum at $\mathrm{pH} 7$. About $50 \%$ activity was maintained at $\mathrm{pH} 12$ and was completely inactivated above $\mathrm{pH} 12$. Exposure to surfactants caused about $15 \%$ inactivation of the antimicrobial activity for the SDS agent and about $40 \%$ for the other tested surfactants (Tween 20, Tween 80, Triton X-100, Urea, EDTA, and PMSF). Concerning the treatment with organic solvents (ethyl acetate, methanol, and isopropanol), no significant alteration of the BacTN635 activity was observed. 




Fig. 3 Purification of BacTN635 by cation-exchange chromatography using Sephadex G-25 monitoring by absorbance at $280 \mathrm{~nm}$ (filled square)

Bacteriocin Purification and Molecular Weight

BacTN635 was purified to homogeneity from a cell-free culture supernatant of $L b$. plantarum sp. TN635 strain by a four-step protocol. Maximum antimicrobial activity was obtained when the cell-free culture supernatant was precipitated with $80 \%$ ammonium sulfate. One hundred forty fractions (F1-F140) with $5 \mathrm{ml}$ each were eluted from a Sephadex G-25 column. These 140 fractions detected using absorption measurements at $280 \mathrm{~nm}$ were fractioned into six samples (S1-S6). After concentration, the antagonistic activity of each sample was essayed using L. ivanovii BUG 496, S. enterica ATCC43972, and C. tropicalis R2 CIP203 as indicator microorganisms. Only sample S5 (F82-F93) possesses inhibitory activity against the three tested cells (Fig. 3). Sample S5 was then applied to another round of purification using the HPLC technique. Three well-defined



Fig. 4 Elution profile of bacteriocin using HPLC reverse-phase chromatography on C18 column monitoring by absorbance at $280 \mathrm{~nm}$ 
Table 3 Purification of BacTN635 produced by Lactobacillus plantarum sp. TN635 strain.

\begin{tabular}{lcclccc}
\hline Step & $\begin{array}{l}\text { Volume } \\
(\mathrm{ml})\end{array}$ & $\begin{array}{l}\text { Total activity } \\
(\mathrm{AU})^{\mathrm{a}}\end{array}$ & $\begin{array}{l}\text { Total } \\
\text { protein }(\mathrm{mg})\end{array}$ & $\begin{array}{l}\text { Specific activity } \\
(\mathrm{AU} / \mathrm{mg})\end{array}$ & $\begin{array}{l}\text { Purification } \\
\text { fold }\end{array}$ & $\begin{array}{l}\text { Yield } \\
\%\end{array}$ \\
\hline Culture supernatant & 900 & $45 \times 10^{5}$ & 2,160 & 2,083 & 1 & 100 \\
Ammonium sulfate precipitation & 50 & $5.2 \times 10^{5}$ & 52.5 & 9,904 & 4.75 & 11.55 \\
Microconcentrators & 32 & $3.32 \times 10^{5}$ & 23.2 & 14,310 & 6.87 & 7.38 \\
Gel filtration & 3.5 & $2.25 \times 10^{5}$ & 1.54 & 146,104 & 70.14 & 5 \\
HPLC & 0.7 & $1.125 \times 10^{5}$ & 0.57 & 197,368 & 94.75 & 2.5 \\
\hline
\end{tabular}

${ }^{a}$ Antibacterial activity (in arbitrary units [AU]) was assayed by agar well diffusion assay using L. ivanovii BUG 496 as an indicator strain

peaks (P1-P3) were obtained having, respectively, the following retention times: P1: 34.55 min, P2: $38.38 \mathrm{~min}$, and P3: 39.31 min (Fig. 4). Only the fraction of the peak P3 possesses an antimicrobial activity against the three tested microorganisms mentioned above and no activity has been observed for the two other fractions. The yield, activity, and purification fold of the BacTN635 of the four various purification steps were summarized in Table 3. SDS-PAGE analysis of the purified BacTN635, revealed a single band with an estimated molecular mass of approximately $4 \mathrm{kDa}$ indicating that this bacteriocin had been purified to homogeneity (Fig. 5a). Antibacterial activity determination against L. ivanovii BUG 496 strain, reveals a growth inhibitory zone at the same position than that visualized in the stained gel (Fig. 5b). During the last few years, a large number of new bacteriocins produced by LAB bacteria have been identified and characterized. However, a few bacteriocins produced by this species have been reported to be active against Gramnegative bacteria and particularly against fungi. Most of the described bacteriocins as antifungal agents from Lactobacillus are organic compounds or diketopiperazine derivatives with low molecular mass, lower than $1 \mathrm{kDa}$ [29]. Too rare are the bacteriocins described from LAB bacteria with a molecular mass higher than $1 \mathrm{kDa}$ and having antifungal activities [30].

Fig. 5 Electrophoretic and zymogram analyses of the purified BacTN635. Coomassie brilliant blue R-250 stained SDS-PAGE gel. Lane 1 molecular mass markers; lane 2 purified BacTN635 (a). Portion of the renaturated SDS-PAGE, overlaid with LB soft agar containing $L$. ivanovii BUG 496 (b)

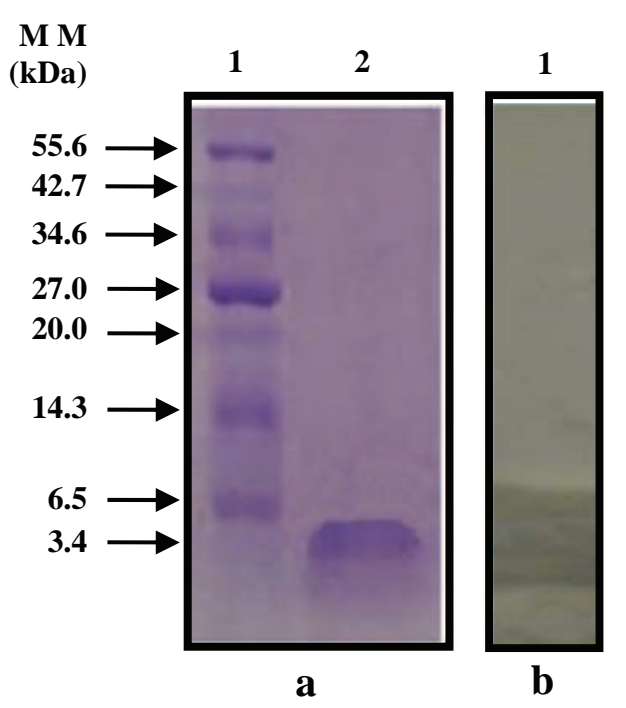


The addition of partial purified BacTN635 (the fraction obtained from gel filtration chromatography and freeze-dried) at $400 \mathrm{AU} / \mathrm{ml}$, to cells of L. ivanovii BUG 496 (3 h old) and C. tropicalis R2 CIP203 (10 h old) in their early logarithmic growth phase, resulted in a rapid decrease in the number of $L$. ivanovii BUG 496 viable cells (from $10^{7} \mathrm{CFU} / \mathrm{ml}$ to less than $10 \mathrm{CFU} / \mathrm{ml}$ ) over a period of $5 \mathrm{~h}$ (Fig. 6a). The optical density readings of this indicator microorganism remained constant since the addition of the BacTN635 (Fig. 6a). These results indicate that the studied bacteriocin exhibits bactericidal effect against $L$. ivanovii BUG 496 strain. Concerning the C. tropicalis R2 CIP203, the optical density readings were very similar in presence and absence of BacTN635 (Fig. 6b). However, we notice an increase of the number of viable cells grown in the absence of the bacteriocin at
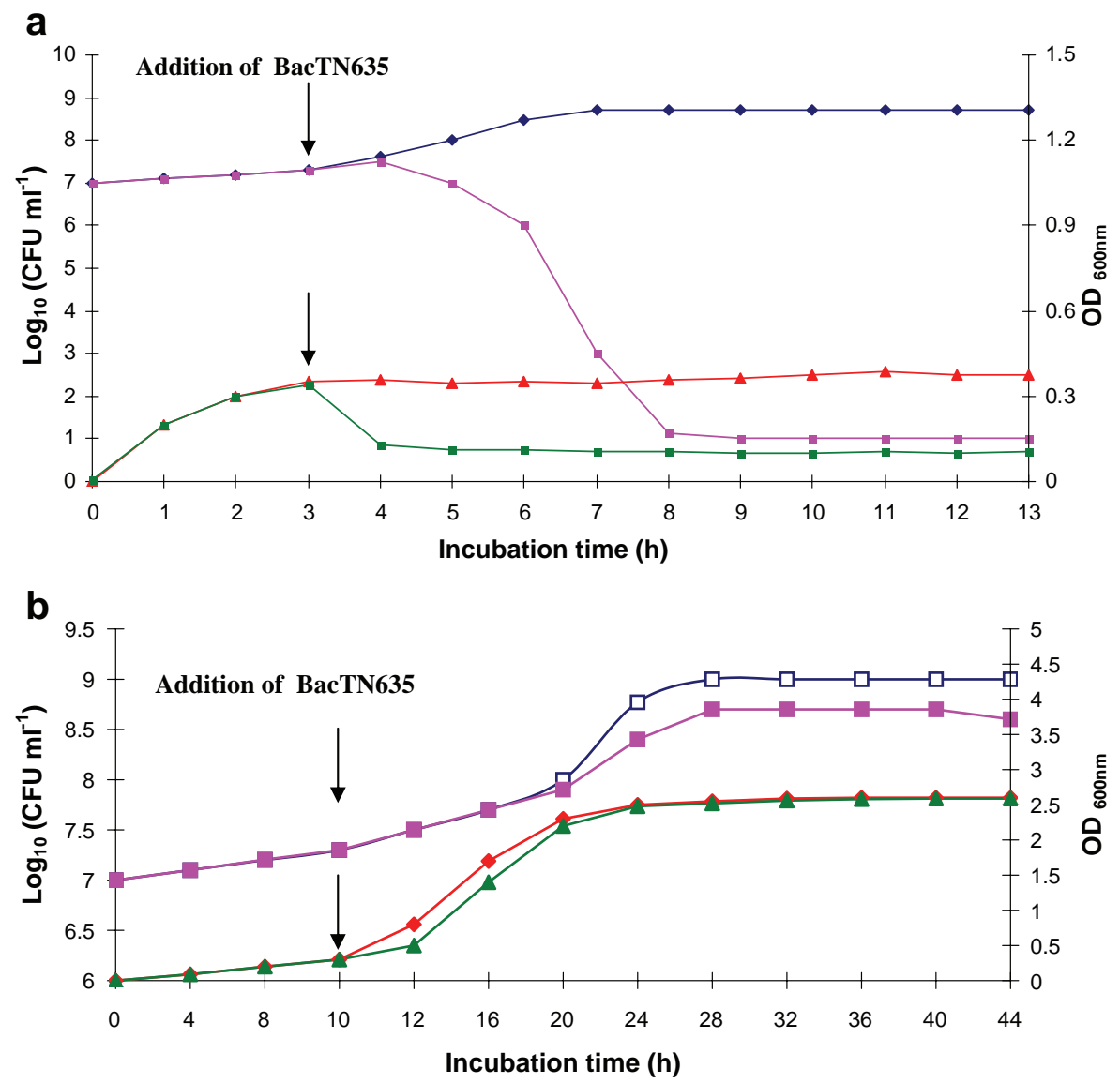

Fig. 6 The effect of BacTN635 on the growth of L. ivanovii BUG 496. Optical density at $600 \mathrm{~nm}$ in absence $(\boldsymbol{\Delta})$ and in presence $(\boldsymbol{\square})$ of BacTN635. Viable cell counts $(\mathrm{CFU} / \mathrm{ml})$ in absence $(\downarrow)$ and in presence $(\boldsymbol{\square})$ of BacTN635 (a). The effect of BacTN635 on the growth of C. tropicalis R2 CIP203. Optical density at $600 \mathrm{~nm}$ in absence $(\bullet)$ and in presence $(\boldsymbol{\Delta})$ of BacTN635. Viable cell counts (CFU/ml) in absence $(\square)$ and in presence $(\mathbf{\square})$ of BacTN635 (b) 
$40 \mathrm{~h}$ of growth (Fig. 6b). These data indicate that BacTN635 acts with a fungistatic effect against C. tropicalis R2 CIP203.

\section{Conclusions}

A new LAB strain has been selected for its antimicrobial activity against pathogenic Gramnegative bacteria and fungi. Based on the analysis of the nucleotide sequence $(1,540 \mathrm{pb})$ of the whole 16S rRNA gene (accession no: FN252881) and the phylogenetic study, we propose the assignment of our new isolate bacterium as Lb. plantarum sp. TN635 strain. The antimicrobial compound of this strain was determined as a proteinaceous substance. The maximum bacteriocin-like substance (BacTN635) production $(5,000 \mathrm{AU} / \mathrm{ml})$ was recorded after a 16 -h incubation in MRS medium at $30^{\circ} \mathrm{C}$. BacTN635 was stable to heat and to treatment with surfactants and organic solvents. Highest antimicrobial activity was found between $\mathrm{pH} 3$ and 11 with an optimum at $\mathrm{pH}=7$. The purified BacTN635, revealed a single band with an estimated molecular mass of approximately $4 \mathrm{kDa}$. BacTN635 produced by $L b$. plantarum sp. TN635 strain, may possess potential practical applications, since it was able to inhibit important Gram-negative pathogenic bacteria such as $(S$. enterica ATCC43972, P. aeruginosa ATCC 49189, Hafnia sp., and Serratia sp.) and pathogenic fungi such as C. tropicalis R2 CIP203. S. enterica is an important cause of human salmonellosis and food-poisoning associated with consumption of contaminated chicken eggs and poultry products [31]. P. aeruginosa is an opportunistic pathogen of humans. It causes urinary tract infections, respiratory system infections, gastrointestinal infections, and a variety of systemic infections, particularly in patients with severe burns and in cancer and AIDS patients who are immunosuppressed [32]. Serratia and Hafnia sp. are usually found in the intestinal tract. These pathogenic bacteria cause s wide variety of infections primarily pneumonia, wound, and urinary tract infections. Moreover, it should be noted that the number of patients with fungal infections has been rising in recent years. In addition to the species Candida albicans and Candida stellatoidea, C. tropicalis is one of the significant pathogenic yeasts in humans belonging to the genus Candida [33].

Acknowledgments This work was supported by the Tunisian government (Contract Program CBS-LEMP) and the CMCU project (2006-2008) No 06/S 0901 "MELLOULI/AIGLE". We are grateful to Dr. M. Ferchichi for providing the indicator bacteria.

\section{References}

1. Alisky, J., Iczkowski, K., Rapoport, A., \& Troitsky, N. (1998). Journal of Infection, 36, 5-15.

2. Macfarlane, G. T., \& Cummings, J. H. (2002). Current Opinion in Infectious Diseases, 15, 501-506.

3. Papagianni, M. (2003). Biotechnology Advances, 21, 465-499.

4. Twomey, D., Ross, R. P., Ryan, M., Meaney, B., \& Hill, C. (2002). Antonie Van Leeuwenhoek, 82, $165-18$.

5. Brooks, G. F., Butel, J. S., \& Morse, S. A. (1998). Jawetz, Melnick, and Adelberg's medical microbiology (p. 269). Upper Saddle River, New Jersey, USA: Appleton \& Lange.

6. Settanni, L., \& Corsetti, A. (2008). International Journal of Food Microbiology, 121, 123-138.

7. Nawaz, S. K., Riaz, S., Riaz, S., \& Hasnain, S. (2009). African. J. Biotechnol., 8, 365-368.

8. Hammami, I., Rhouma, A., Jaouadi, B., Rebai, A., \& Nesme, X. (2009). Letters in Applied Microbiology, 48, 253-260. 
9. Diop, M. B., Dubois-Dauphin, R., Tine, E., Ngom, A., Destain, J., \& Thonart, P. (2007). Biotechnology, Agronomy, Society and Environment, 11, 275-281.

10. Paul, R. R., Morgan, S., \& Hill, C. (2002). International Journal of Food Microbiology, 79, 3-16.

11. Messi, P., Bondi, M., Sabia, C., Battini, R., \& Manicardi, G. (2001). International Journal of Food Microbiology, 64, 193-198.

12. Todorov, S. D., \& Dicks, L. M. (2004). Journal of Basic Microbiology, 44, 305-316.

13. Todorov, S. D., \& Dicks, L. M. (2005). Enzyme and Microbial Technology, 36, 318-326.

14. Todorov, S. D., Nyati, H., Meincken, M., \& Dicks, L. M. T. (2007). Food Control, 18, 656-664.

15. Hanahan, D. (1983). Journal of Molecular Biology, 16, 557-580.

16. Janssen, G. R., \& Bibb, M. J. (1993). Gene, 124, 133-134.

17. Sambrook, J., Fritsch, E. F., \& Maniatis, T. (1989). Molecular cloning: a laboratory manual (2nd ed.). New York: Cold Spring Harbor Laboratory Press.

18. Leenhouts, K. J., Kok, J., \& Venema, G. (1990). Applied and Environmental Microbiology, 56, 27262735.

19. Lee, C. M., Sieo, C. C., Abdullah, N., \& Ho, Y. W. (2008). FEMS Microbiology Letters, 287, $136-141$.

20. Thompson, J. D., Higgins, D. G., \& Gibson, T. J. (1994). Nucleic Acids Research, 22, 4673-4680.

21. Felsenstein, J. (1989). PHYLIP-Phylogeny Inference Package, version 3.2. Cladistics, 5, 164-166.

22. Saitou, N., \& Nei, M. (1987). Molecular Biology and Evolution, 4, 406-425.

23. Tagg, J. R., \& McGiven, A. R. (1971). Applied Microbiology, 21, 943.

24. Laemmli, U. K. (1970). Nature, 227, 680-685.

25. Bradford, M. M. (1976). Analytical Biochemistry, 72, 248-254.

26. Karunasagar, I., Krohne, G., \& Goebel, W. (1993). Infection and Immunity, 61, 162-169.

27. Atanassova, V., Meindl, A., \& Ring, C. (2001). International Journal of Food Microbiology, 68, 105113.

28. Aktypis, A., Kalantzopoulos, G., Huis IN'T Veld, J. H. J., \& Ten Brink, B. (1998). Journal of Applied Microbiology, 84, 568-576.

29. Lavermicocca, P., Valerio, F., Evidente, A., Lazzaroni, S., Corsetti, A., \& Gobbetti, M. (2000). Applied and Environmental Microbiology, 66, 4084-4090.

30. Atanassova, M., Choiset, Y., Dalgalarrond, D., Chobert, J. M., Dousset, X., Ivanova, I., et al. (2003). International Journal of Food Microbiology, 8, 63-73.

31. Erich, L., \& Martin, J. (1997). Antimicrobial food additives, characteristics, uses, effects (2nd Ed.). Translated by S.F. Laichena Berlin: Springer.

32. Wiblin, R. T. (1997). Nosocomial pneumonia. In R. P. Wenzel (Ed.), Prevention and control of nosocomial infections (3rd ed., pp. 807-819). Baltimore: Williams and Wilkins.

33. Kobayashi, H., Matsuda, K., Ikeda, T., Suzuki, M., Takahashi, S., Suzuki, A., et al. (1994). Infection and Immunity, 62, 615-622. 